\title{
Status of Wetland in Dhorpatan Hunting Reserve, Nepal
}

\author{
Saroj Panthi ${ }^{*}$, Maheshwar Dhakal'2, Sher Singh Thagunna², Barna Bahadur Thapa ${ }^{2}$ \\ ${ }^{1}$ Department of National Parks and Wildlife Conservation, Api Nampa Conservation Area, Darchula, Nepal \\ ${ }^{2}$ Department of National Parks and Wildlife Conservation, Kathmandu, Nepal \\ Email: mountsaroj@gmail.com
}

Received 2 November 2013; revised 2 January 2014; accepted 10 January 2014

Copyright (C) 2014 by authors and Scientific Research Publishing Inc.

This work is licensed under the Creative Commons Attribution International License (CC BY).

http://creativecommons.org/licenses/by/4.0/

CC) (i) Open Access

\begin{abstract}
Wetland means the surface of the earth that is permanently or seasonally or partially covered with water. Wetlands are most productive areas for biodiversity and local livelihood support. Nepal ratified Ramsar convention in 1987 and started to include the wetland in Ramsar site and till now nine wetland sites are included in Ramsar site. There are still lacking systematic research and conservation approach for these wetlands; therefore, our study attempted to assess the status of wetlands in the Dhorpatan Hunting Reserve, Nepal; and explored threats and conservation challenges. We prepared list of streams and lakes and collected detail information regarding area, district, block, elevation and cultural as well as ecological importance of lakes. We recorded total 11 lakes with total $304477 \mathrm{~m}^{2}$ areas. The Sundaha lake is largest lake of the reserve having significant religious importance. We also recorded 7 streams in the reserve. Wetlands of the reserve were facing problem of sedimentation, pollution, and change in climate has also effects on these wetland ecosystem and their importance.
\end{abstract}

\section{Keywords}

Dhorpatan Hunting Reserve, High Altitude, Lake, Wetland

\section{Introduction}

Wetland, in Nepali term "SIMSAR" means field with perennial source of water including swampy paddy fields, water logged areas and ponds. Wetlands are most productive areas for biodiversity conservation [1].

Wetlands are a crosscutting sector, multidisciplinary in nature and therefore, require a common understanding and integrated approach towards its conservation and wise use of resources [2]. Nepal has many different types

\footnotetext{
Corresponding author.
} 
of wetlands that range from areas of permanently flowing rivers to areas of seasonal streams, lowland oxbow lakes, high altitude glacial lakes, swamps and marshes, paddy fields, reservoirs and ponds [3]. The Government of Nepal ratified the Ramsar Convention in 1987 and has incremented its contribution to the list of wetlands of international importance to currently include nine wetlands with a surface area of 34,455 hectares [4]. Out of them Koshi Tappu Wildlife Reserve is the largest and the first Ramsar site of international importance of Nepal and Mai Pokahri is a smallest and youngest Ramsar site [5]. Ramsar sites of Nepal are representing 0.19\% of total area of global Ramsar sites. In Nepal 193 bird species are known to be dependent on wetlands [3] [6]-[11] and 172 species of the major wetland plants are listed by IUCN [12]. Wetland plants provide food, forage and cover for both domestic and wild animals. Wetlands are also one of the most threatened habitats because of their vulnerability and attractiveness for development [13].

The systematic study of wetlands in Nepal is very recent [14]. In Nepal 163 wetlands are situated in Terai, and 79 in the hills and mountains [15]. Wetlands continue to be degraded and lost despite their immense ecological, economic and socio-cultural values [16]. The Department of National Parks and Wildlife Conservation (DNPWC) is the administrative authority of the Ramsar convention in Nepal [4]. Dhorpatan Hunting Reserve (DHR) is only one hunting reserve managed under DNPWC with no any scientific data about wetlands. In this study, we found out the preliminary information of wetlands of DHR. Main wetland sites are lakes and streams in DHR so we listed the name of streams and prepared the detail information on lakes.

\section{Materials and Methods}

\subsection{Study Area}

The Dhorpatan Hunting Reserve (DHR) is the only one hunting reserve in Nepal located in Dhaulagiri Himal range [17] [18]. The reserve was established in 1983 and gazetted in 1987. The reserve covers $1,325 \mathrm{~km}^{2}$ and ranges from 2000 to $7246 \mathrm{~m}$ (elevation). It falls within the Rukum, Baglung and Myadgi districts of Nepal (Figure 1). It consists of 7 hunting blocks viz. Barse, Dogadi, Fagune, Gustung, Seng, Sundaha and Surtibang [19]. The reserve supports 14 ecosystems types represented in the mid hill to higher Himalayan ecosystem [20]-[22]. The reserve provide prime habitat for fauna such as barking deer (Munticus muntjak), blue sheep (Pseudois nayaur), common leopard (Panthera pardus), goral (Naemorhedus goral), Himalayan tahr (Hemitragus jemlachicus), Himalayan black bear (Ursus thibetans), red panda (Ailurus fulgens fulgens), rhesus macaque (Macaca radiata), serow (Capricornis tahr), wild boar (Sus scorfa), wolf (Canis lupus) [17] [18] and 149 species of avifauna including cheer pheasant (Catreus wallichi) and danphe (Lopophorus impegians [23]. Many lakes, streams, mountains and Himalayas are situated in DHR.

\subsection{Listing the Streams and Lakes}

During February to March 2013, we analyzed Topo maps and conducted the interviews of reserve staffs and local key informants to find out the information about streams and lakes and during April to May 2013 we visited these streams and lakes to collect information about each wetland, measure their areas, explore threats and gather the additional information to understand status of each wetland. We listed out the streams of study area and districts on which lakes and streams are existed.

\subsection{Area Calculation}

We collected the GPS points of boundary of famous lakes. We recorded elevation by the help of GPS and we

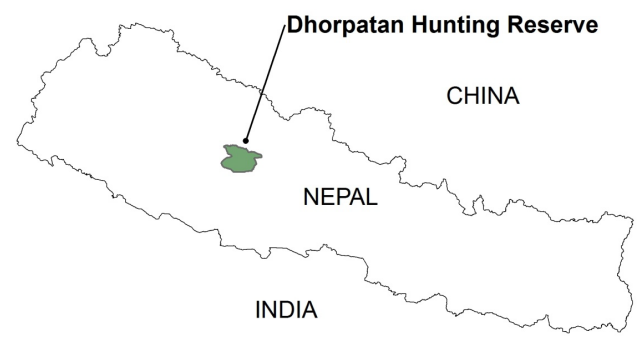

Figure 1. Dhorpatan Hunting Reserve. 
took photographs also by the help of digital camera. In DHR office we prepared the maps of all lakes and calculate the each wetland area with the help of Arc GIS 9.3. During field study, we gathered additional information on ecological and cultural importance of each site.

\section{Results and Discussion}

\subsection{Streams}

We recorded 7 streams in the reserve (Table 1). Uttarganga Khola (Khola refers to small river) is most famous stream having religious importance. It is longest than others. It is known as Sani Veri river at the outer side of reserve. Rukum district covers the $60 \%$ area of the reserve so this district is also rich in wetland than other districts. Tatopani Khola is also known as Seng Khola in Seng block but it is widely known as Tatopani Khola (hot water stream) throughout the reserve. These perennial streams are supporting the wildlife for drinking water throughout the reserve.

\subsection{Lakes}

We recorded total 11 famous lakes in the study area (Table 2). Total $304477.098 \mathrm{~m}^{2}$ area is covered by lakes in the reserve. Lake Sundaha (gold pond) is largest lake of the reserve having the religious importance. It covers

Table 1. Streams of Dhorpatan Hunting Reserve with their situated blocks and districts.

\begin{tabular}{ccccr}
\hline S.N. & Name & Block & District & Remarks \\
\hline 1 & Ghustung Khola & Ghustung & Myagdi, Baglung, Rukum & \\
3 & Gurjaghat Khola & Barse & Myagdi \\
4 & Gurugard Khola & Barse & Myagdi, Baglung \\
5 & Ranma Khola & Sundaha & Rukum \\
6 & Tatopani Khola & Ghustung, Seng & Rukum \\
7 & Uttarganga Khola & Barse, Fagune & Myagdi, Baglung, Rukum \\
\hline
\end{tabular}

Table 2. Lakes of Dhorpatan Hunting Reserve with their situated blocks and districts.

\begin{tabular}{ccccccc}
\hline S.N. & Name of lake & Area $\left(\mathrm{m}^{2}\right)$ & Elevation $(\mathrm{m})$ & Block & District & Remarks \\
\hline 1 & Bhujunge & 14487.5 & 4277 & Ghustung & Myagdi & Figure 2 \\
2 & Ganaune & 1209.5 & 3057 & Fagune & Baglung & Figure 3 \\
3 & Jalpa & 14090.5 & 4284 & Fagune & Baglung & Figure 4 \\
4 & Laden First & 4961 & 4744 & Dogadi & Rukum & Figure 5 \\
5 & Laden Second & 20974.078 & 4735 & Dogadi & Rukum & Figure 6 \\
6 & Parmi & 20443.68 & 4440 & Ghustung & Rukum & Figure 7 \\
7 & Pupal & 3210 & 4355 & Seng & Rukum & Figure 8 \\
8 & Rakesh & 291 & 3824 & Dogadi & Rukum & Figure 9 \\
9 & Rakshes & 14324 & 4715 & Sundaha & Rukum & Figure 10 \\
11 & Sundaha & 172996.84 & 4430 & Sundaha & Rukum & Figure 11 \\
\hline 10 & Warmi & 37489 & 4485 & Ghustung & Rukum & Figure 12 \\
\hline
\end{tabular}




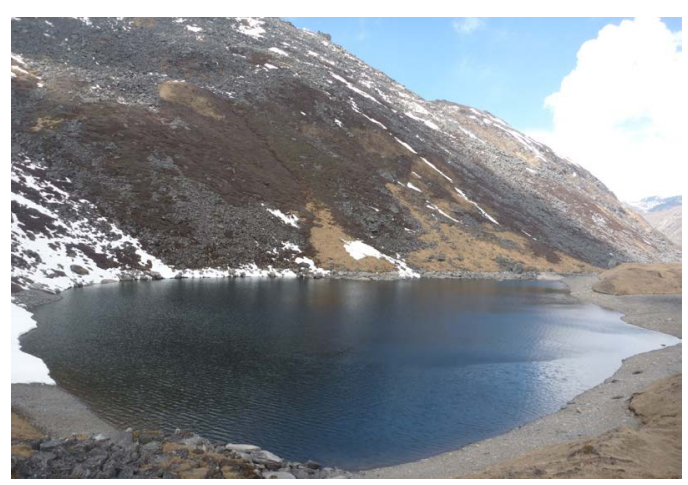

Figure 2. Lake Bhujunge: Photo by Ramesh Poudel.

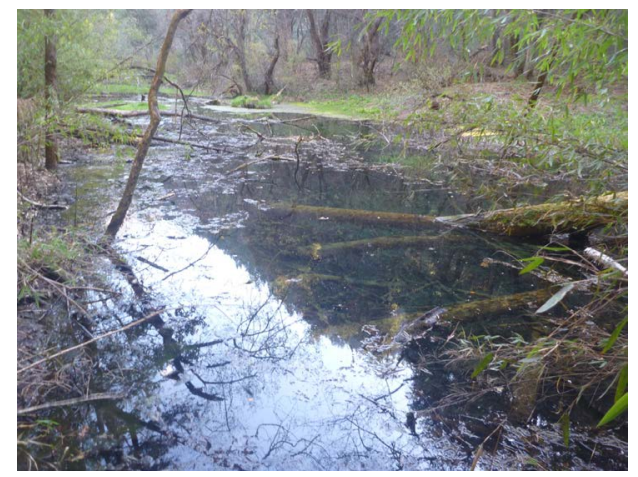

Figure 3. Lake Ganaune: Photo by Saroj Panthi.

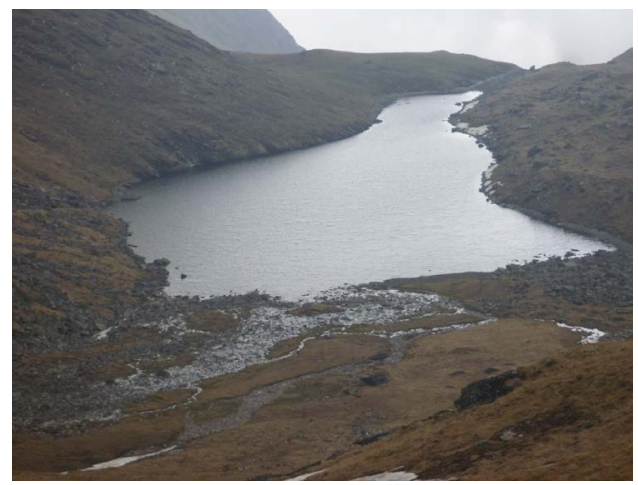

Figure 4. Lake Jalpa: Photo by Pradeep Poudel.

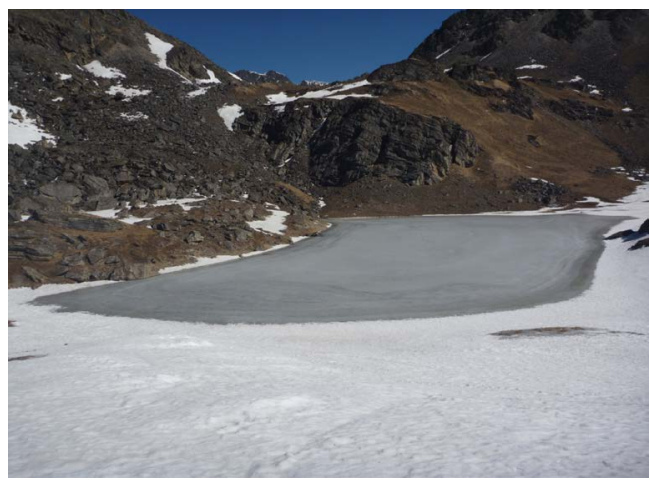

Figure 5. Lake Laden First: Photo by Saroj Panthi. 


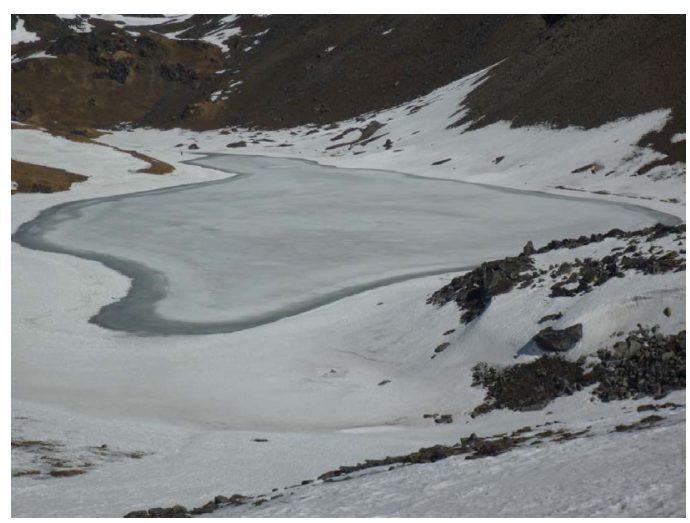

Figure 6. Lake Laden Second: Photo by Saroj Panthi.

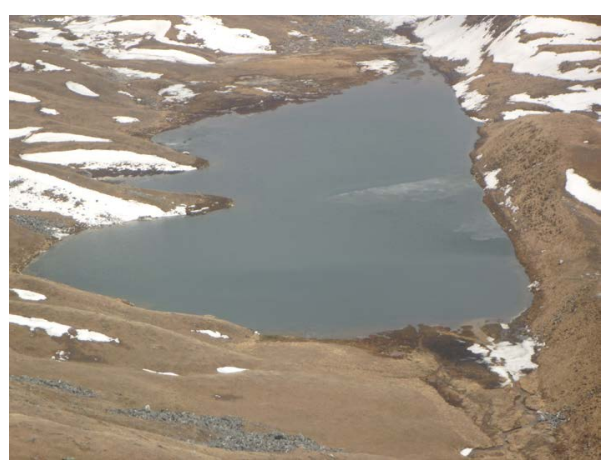

Figure 7. Lake Parmi: Photo by Saroj Panthi.

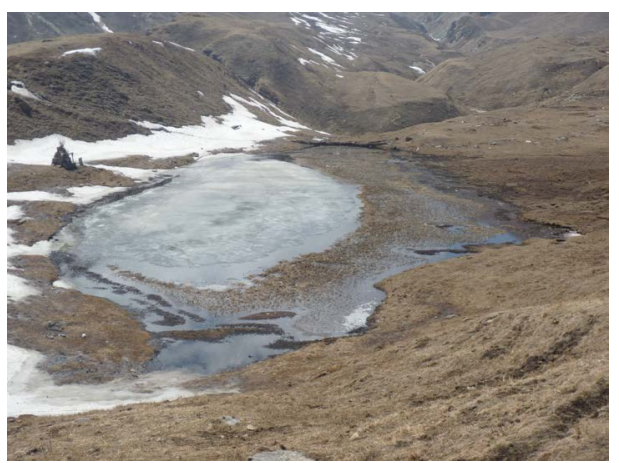

Figure 8. Lake Pupal: Photo by Saroj Panthi.

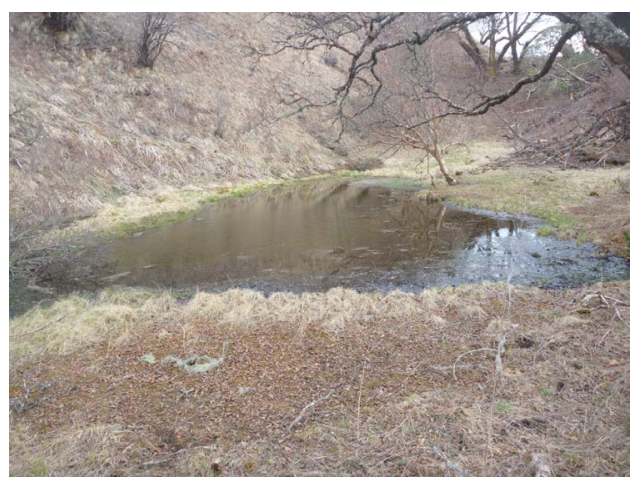

Figure 9. Lake Rakesh: Photo by Saroj Panthi. 


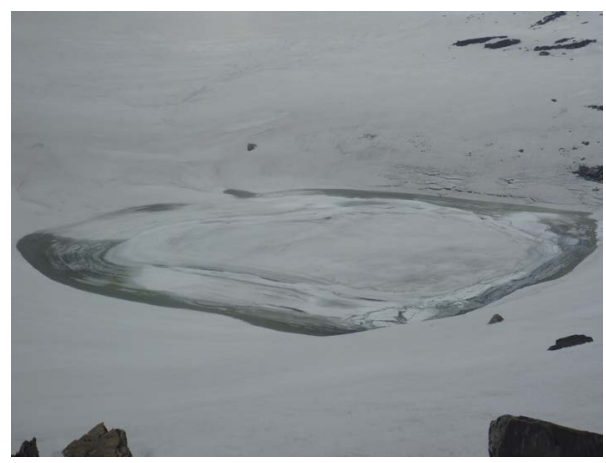

Figure 10. Lake Rakshes: Photo by Saroj Panthi.

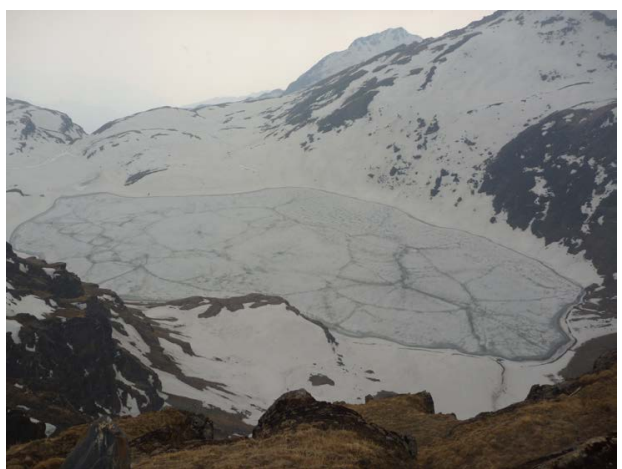

Figure 11. Lake Sundaha: Photo by Saroj Panthi.

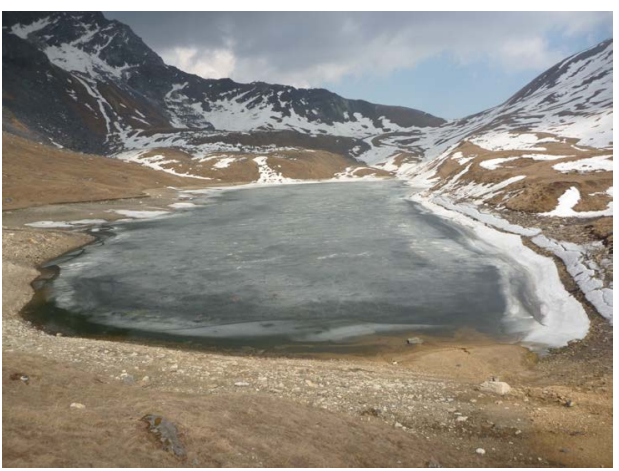

Figure 12. Lake Warmi: Photo by Saroj Panthi.

more than 17 hectares area. Local herders pray to god of this lake to save own cattle from wild predator. Lake Laden first is situated at highest elevation. Most of the lakes are situated in Rukum district (Figure 13). Only one lake is situated in Myagdi district. Lake Rakesh is smallest lake covering only $291 \mathrm{~m}^{2}$ but having the religious importance. Most of the lake area falls on the elevation range between $4400 \mathrm{~m}$ - $4800 \mathrm{~m}$ (Figure 14). No any lake is recorded in more than $4800 \mathrm{~m}$ elevation and only one lake Ganaune (bad smelling) is recorded in below 3800 m elevation.

\section{Conclusion}

Dhorpatan Hunting Reserve is rich in wetland sites. These wetlands play vital role in wetland biodiversity conservation within the reserve. Wetlands are prime sources of drinking water for wildlife as well as humans living around the reserve; it has been supporting different diversity of culture and having religious importance with each site. The reserve supports 14 ecosystems types [20]-[22] and each wetland site provided unique support to sustain these ecosystems. During study we recorded some water birds in lakes and streams. Some lakes like 


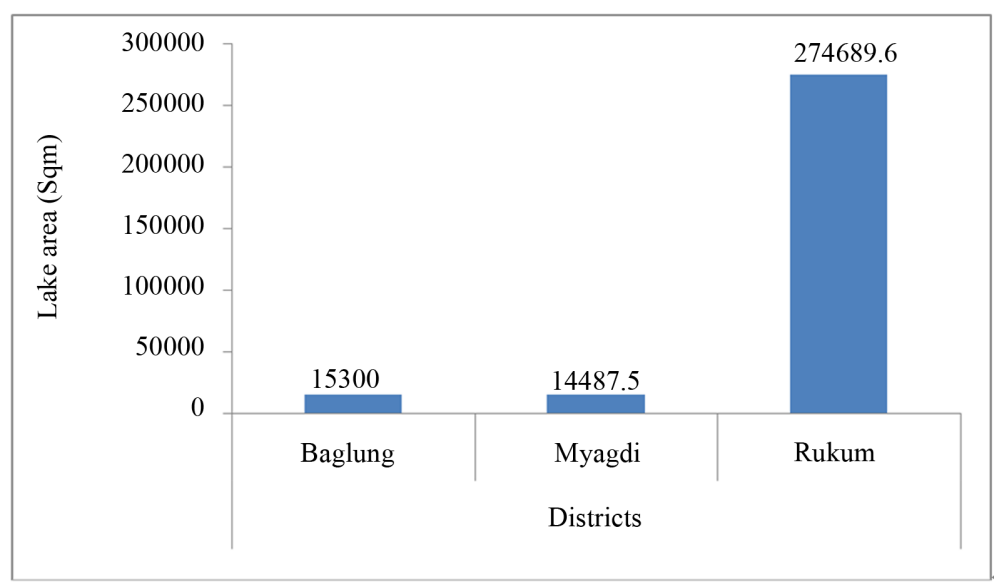

Figure 13. District wise distribution of lake area in DHR.

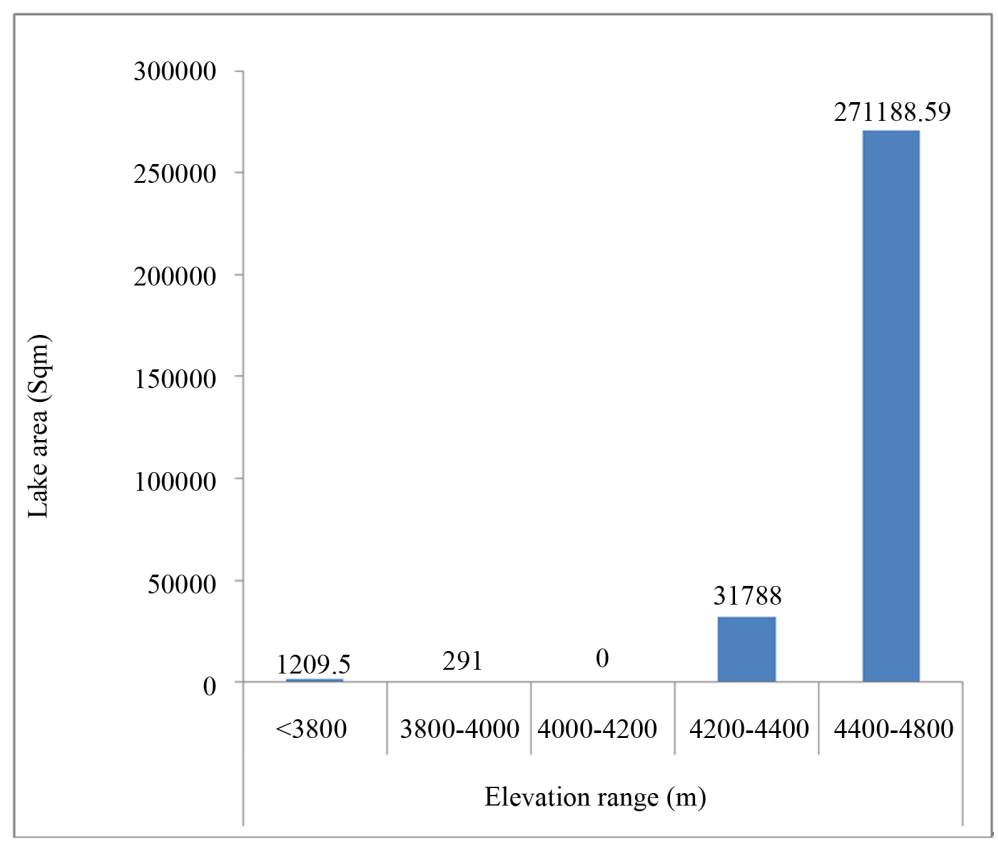

Figure 14. Elevation range wise distribution of lake area in DHR.

Ganaune, Pupal and Rakesh were getting polluted as well as loosing size due to siltation. It is essential to pay attention to conserve the natural beauty of these lakes and to control the pollution. A management authority should conduct the program to manage these lakes. This study found out the preliminary data about the wetlands of DHR. This information would be useful for further management of wetland in the reserve. Climate change was impacting Himalaya biodiversity [24], we also concluded that the change in such climate in the DHR might also impact in wetlands biodiversity and its sustainability, therefore, further study on climate change impact on wetland ecosystem is necessary. The lake Sundaha is relatively large and nearer to the lake Rakshes (Monster) and supporting the wetland birds so it is necessary to study to include it in Ramsar site.

\section{Acknowledgements}

The study was possible after the financial and logistic support from the DHR office. We thank to all staffs of DHR who helped for field survey and IDEA WILD, USA for equipment support. We also thank Dr. Achyut Aryal (Institute of Natural and Mathematical Sciences, Massey University, New Zealand) for his guidance to complete this study. 


\section{References}

[1] CSUWN (2013) http://www.wetlands.org.np/uploads/publications/file/Simsar\%20Varnamala3_20110823115658.pdf

[2] Conservation and Sustainable Use of Wetlands in Nepal (CSUWN) (2012) Simsar Newsletter, 14.

[3] Scott, D.A. (1989) A Directory of Asian Wetlands. IUCN, Gland.

[4] Department of National Parks and Wildlife Conservation (2010) Communication, Education, Participation and Awareness (CEPA) Strategy and Dissemination Framework for the Conservation and Wise Use of Wetland in Nepal (2011-2015).

[5] Amatya, S. and Shrestha, K.R. (2010) Nepal Forestry Hand Book. Nepal foresters’ Association Kathmandu Nepal.

[6] Baral, H.S., Inskipp, C., Inskipp, T. and Regmi, U.R. (1996) Threatened Birds of Nepal. Bird Conservation Nepal and Department of National Parks and Wildlife Conservation, Kathmandu, Nepal.

[7] Choudhary, H. (1996) Bird Conservation Nepal Newsletter, Vol. 5, No. 2, June, Kathmandu, Nepal.

[8] Halliday, J.B. (1982) A Study of the Ecological Distribution of Resident and Migratory Birds Along the Rapti and Narayani Rivers in the Royal Chitwan National Park, November and December 1982. A report to the Department of National Parks and Wildlife Conservation, Kathmandu. Nepal.

[9] Inskipp, C. and Inskipp, T. (1991) A Guide to the Birds of Nepal. Croom Helm, London.

[10] Suwal, R.N. and Shrestha, M.K. (1990) Large Waders and Wetlands of Terai: A Survey Report. US Fish and Wildlife Service and King Mahendra Trust for Nature Conservation, Kathmandu, Nepal.

[11] Perennou, C., Mundkur, T., Scott, D.A., Follestad, A. and Kvenild, L. (1994) The Asian Waterfowl Census 1987-91: Distribution and Status of Asian Waterfowl. AWB Publication No. 86; IWRB Publication 140. 24. Asian Wetlands Bureau, Kuala Lumpur, and IWRB, Slimbridge.

[12] IUCN-Nepal (1996) An Inventory of Nepal’s Wetlands. IUCN-Nepal, Kathmandu.

[13] Hollis, G.E., Holland, M.M. and Larson, J.S. (1988) Wise Use of Wetlands. Nature and Resources, 24, 2-13

[14] HMGN/MFSC (2002) Nepal Biodiversity Strategy.

[15] IUCN-Nepal (1998) An Inventory of Nepal's Wetlands. IUCN-Nepal, Kathmandu.

[16] Conservation and Sustainable Use of Wetlands in Nepal (CSUWN) (2011) Simsar Newsletter, 10.

[17] Aryal, A. and Kreigenhofer, B. (2009) Summer Diet Composition of the Common Leopard Panthera pardus (Carnivora: Felidae) in Nepal. Journal of Threatened Taxa, 1, 562-566. http://dx.doi.org/10.11609/JoTT.02287.562-6

[18] Panthi, S., Aryal, A., Lord, J., Adhikari, B. and Raubenheimer, D. (2012) Summer Diet and Habitat Ecology of Red Panda (Ailurus fulgens fulgens) in Dhopatan Hunting Reserve, Nepal. Zoological Studies, 51, 701-709.

[19] Thapa, B.B. (2007) Dhorpatan Sikar Aararksha ko Parichaya. Baglung, Department of National Park and Wildlife Conservation, DHR Office, Nepal.

[20] Shrestha, T.B., Lillesø, J.P.B., Dhakal, L.P. and Shrestha, R. (2002) Forest and Vegetation Types of Nepal: MFSC, HMG/Nepal, Natural Resource Management Sector Assistance Programme (NARMSAP) and Tree Improvement and Silviculture Component (TISC), Kathmandu.

[21] Lillesø, J.P.B., Shrestha, T.B., Dhakal, L.P., Nayaju, R.P. and Shrestha, R. (2005) The Map of Potential Vegetation of Nepal-A Forestry/Agroecological/Biodiversity Classification System: Forest \& Landscape. Development and Environment Series 2-2005 and CFC-TIS Document Series No.110. Denmark.

[22] Bhuju U.R., Shakya P.R., Basnet, T.B. and Shrestha, S. (2007) Nepal Biodiversity Resource Book: Protected Areas, Ramsar Sites, and World Heritage Sites. ICIMOD and MOEST, Government of Nepal in cooperation with UNEP, Kathmandu.

[23] Panthi, S. and Thagunna, S.S. (2013) Birds of Dhorpatan Hunting Reserve, Nepal. Open Journal of Forestry, 3, 109114. http://dx.doi.org/10.4236/ojf.2013.34018

[24] Aryal, A., Brunton, D. and Raubenheimer, D. (2103) Impacts of Climate Change on Human-Wildlife-Ecosystem Interactions in the Trans-Himalayan Region of Nepal. Theoretical and Applied Climatology, 115, 517-529. http://dx.doi.org/10.1007/s00704-013-0902-4 